\title{
AMICI IN CHURCH-STATE LITIGATION
}

\author{
Leo Pfeffer* \\ I \\ INTRODUCTORY
}

Intervention as amicus curiae may be traced as far back as Roman law, ${ }^{1}$ but its utilization in almost every case involving First Amendment freedoms generally, and church-state litigation specifically, ${ }^{2}$ that reach the United States Supreme Court is a comparatively recent development. Amici briefs were submitted as early as 1925 to support a suit challenging the constitutionality under the Fourteenth Amendment's Due Process Clause of an Oregon statute aimed at elementary parochial schools. ${ }^{3}$ Thereafter, briefs amici were submitted by the Bill of Rights Committee of the American Bar Association ${ }^{4}$ and the American Civil Liberties Union (hereinafter, ACLU) ${ }^{5}$ in cases involving Jehovah's Witnesses, who, for reasons of religious conscience, refused to salute the flag.

It was, however, not until after the conclusion of World War II that submission of briefs amici curiae in cases involving not only the Free Exercise, but even more, the Establishment Clause became almost standard practice, at least in cases that were accepted by the Supreme Court for review. The reason for the predominance of Establishment over Free Exercise cases lies in large measure in the fact that after the conclusion of the war (and perhaps also because of the Supreme Court's

Copyright 1981 by Duke University

* Professor of Constitutional Law, Long Island University; Special Counsel, American Jewish Congress.

1. This article is based in a substantial measure on the author's personal involvement as counsel for the American Jewish Congress and other amici curiae in most of the cases dealt with herein. In preparing the article the author used materials that are in the files of the American Jewish Congress but are not otherwise easily available. Readers seeking further information on a particular point should communicate with the author at the office of the organization, 15 East 84th Street, New York, N.Y. 10028. Krislov, The Amicus Curiae Brief: From Friendship to Adwocacy, 72 Y ALE L. J. 694 (1963). For a general consideration of the role of the amicus see, also, Angell, The Amicus Curiae: American Development of English Institutions, 16 INT'L \& CoMP. L. Q. 1017 (1967). For its recent introduction in Canada (in a case involving illegal abortions), see Dickens, A Canadian Development: Non-Party Intervention, 40 MOD. L. REv. 666 (1977).

2. The term "church-state" as used in this article is intended to apply not only to cases arising under the Establishment Clause, but also, unless the text indicates otherwise, to those under the Free Exercise Clause.

3. Pierce v. Society of Sisters, 268 U.S. 510 (1925). The briefs were submitted by the American Jewish Committee, the North Pacific Union Conference of Seventh Day Adventists, and The Domestic and Foreign Missionary Society of the Protestant Episcopal Church. Id., at 529.

4. Johnson v. Deerfield, 306 U.S. 621 (1939); Minersville School District v. Gobitis, 310 U.S. 586, 591 (1940); West Virginia State Board of Education v. Barnette, 319 U.S. 624, 625 (1943).

5. D. Manwaring, Render Unto Caesar: The Flag-Salute Controversy 66 (1962); Minersville School District v. Gobitis, 310 U.S. 586, 581 (1940); West Virginia State Board of Education v. Barnette, 319 U.S. 624, 625 (1943). The substance of these briefs and of Johnson v. Deerfield, 306 U.S. 621 (1939), are set forth in MANwaring, supra. 
decision in West Virginia State Board of Education v. Barnette ${ }^{6}$ ), the American people and their representatives in government have become considerably more tolerant of religious than of political dissent. ${ }^{7}$

The dichotomy between free exercise and establishment is by no means incontrovertible. In the words of Justice Rutledge, “' $[\mathrm{e}] \mathrm{stablishment'} \mathrm{and} \mathrm{'free} \mathrm{exercise'}$ were correlative and coextensive ideas, representing only different facets of the single great and fundamental freedom." ${ }^{8}$ Nevertheless, there can be little doubt that in later opinions the Supreme Court has recognized the existence of such a dichotomy, and thus the possibility of a conflict between them. ${ }^{9}$

It is, therefore, not surprising that in cases involving the First Amendment's Religion Clauses, amici can be found on both sides, some urging a determination on the basis of the Establishment Clause, and others a contrary determination by reason of Free Exercise. Thus, in Walz $v$. Tax Commission, ${ }^{10}$ an amicus brief was filed by the ACLU supporting the plaintiffs' position that a statute exempting church property from real estate taxes violated the Establishment Clause, while in the same case a brief was filed by the National Council of Churches of Christ in the United States (hereinafter, NCC) arguing that non-exemption would violate the Free Exercise Clause.

Similarly, in Poelker $v$. Doe, ${ }^{11}$ and again in Harris $v . M c R a e,{ }^{12}$ a group of organizations affiliated with the Religious Coalition for Abortion Rights, filed briefs amici asserting that denial of municipal hospital services or Medicaid benefits for abortions violated the Establishment Clause, while other religious organizations, mostly but by no means only Catholic, asserted that use of tax-raised funds to finance abortions violated the Free Exercise rights of taxpayers whose religious conscience forbade abortions. ${ }^{13}$

A number of factors explain the proliferation of amici briefs in church-state litigation in the post-World War II period. One of them was the rapid growth of

6. 319 U.S. 624 (1943). The case was decided on freedom of speech grounds, but the crux in this and the other Jehovah's Witnesses cases was religion, not speech. Utilization of speech freedom was necessitated in the early cases by the fact that it was not until 1940 that the Court, in Cantwell v. Connecticut, 310 U.S. 296, held that freedom of religion was incompassed within the Due Process Clause of the 14th Amendment and thus applicable to the states. Incorporation of establishment was effected seven years later in Everson v. Board of Education, 330 U.S. 1 (1947).

7. The exemption for compulsory military service of persons whose religious conscience forbids their participation can be traced at least as far back as the Civil War. United States v. Seeger, 380 U.S 163, 170 (1965). Persons who refuse to serve for political reasons are not exempt. Id., at 172.73.

8. Everson v. Board of Education, 330 U.S. 1, 40 (1947). Although Justice Rutledge's statement was made in a dissenting opinion, there was no disagreement with this point in the majority opinion.

9. See Wisconsin v. Yoder, 406 U.S. 205, 220-221 (1972); Abington School District v. Schempp, 374 U.S. 203, 296 (Brennan, J., concurring); Harris v. McRae, 100 S. Ct. 2671 (1980). See also, Pfeffer, Freedom andlor Separation: The Constitutional Dilemma of the First Amendment, 64 Mins. L. Rev. 561 (1980).

10. 397 U.S. 664 (1970).

11. 432 U.S. 519 (1977).

12. 100 S. Ct. 2671 (1980).

13. In Poelker and in Harris both the appellees and the amici in urging affirmance invoked the Free Exercise as well as the Establishment Clause. Major reliance, however, rested upon the Establishment Clause. 
the ACLU as a potent defender of religious freedom and church-state separation. Another was the entry into the litigation arena of the American Jewish Congress (hereinafter, AJC), and to a somewhat lesser extent other Jewish organizations, such as the Synagogue Council of America, the American Jewish Committee (hereinafter, AJCommittee), the Anti-Defamation League of B'nai B'rith (hereinafter, the $\mathrm{ADL}$ ), and more recently the Jewish Committee on Law and Political Action (hereinafter, COLPA).

American Protestantism, too, entered the arena of litigation, mostly through submission of briefs amici. The NCC, the major Protestant organization in the country, the Baptist Joint Committee on Public Affairs, and Protestants and Other Americans United for Separation of Church and State, which later became Americans United for Separation of Church and State (hereinafter, AU), were the leading spokesmen for Protestantism.

Catholic organizations entered the arena of church-state litigation more recently, and to a considerably smaller extent than the non-Catholic. More will be said of these amici, religious and non-religious, shortly; first, however, a word must be said regarding the rule of the Supreme Court regulating amici intervention, a rule that manifests judicial recognition that the multiplication of amici briefs imposes an additional burden upon an already overburdened Court.

Basically, the rule ${ }^{14}$ requires that unless consent of the parties to the filing of a brief is obtained, a motion for leave to file must be made. In early days, the Court was quite liberal in granting such motions. This was followed by a period during which the Court rarely granted them. ${ }^{15}$ More recently, however, the Court has returned to its earlier days of liberality, and grants these motions in the overwhelming majority of the cases, sometimes even when the motion is made before the Court has granted certiorari or noted probable jurisdiction. ${ }^{16}$

The rule requires that a motion for leave to file must set forth reasons for believing that the questions of law to which it is addressed have not or "will not be adequately presented by the parties." On its face, this seems to be a quite reasonable requirement; the tremendous burden already carried by the Justices and their clerks would seem to justify some restrictions upon the free flow of briefs. However, it appears that the requirement has become pretty much of a dead letter, and motions are granted freely even in respect to amicus briefs (and these are quite likely the majority) which do little if anything more than restate the arguments set forth in the briefs of the parties supported by the amicus. In any event, if the requirement makes sense, it would seem to be appropriate whether or not the parties consent to submission.

14. Rules of the Supreme Court, Rule 36

15. R. Stern \& E. Gressman, Supreme Court Practice 728 (5th ed. 1978). See, e.g., denial of motion to submit brief amici in NAACP v. Alabama, 355 U.S. 860 (1957).

16. E.g., Worldwide Church of God v. Superior Court, 100 S. Ct. 2974 (1980). See note 139, infra. The current liberality of the Court in respect to amicus briefs is further indicated by a rule adopted in October, 1980, requiring a listing of parent corporations, subsidiaries and affiliates of corporate parties except in respect to amicus briefs. Amendment to Supreme Court Rules 28.1, $101 \mathrm{~S}$. Ct. LXXIV. 
What has been said in this section of the article involves briefs filed in the Supreme Court. ${ }^{17}$ Recently, however, in the areas covered in this article, there has been an ever-increasing number of amicus briefs submitted in the Federal Courts of Appeal ${ }^{18}$ and even in the District Courts. ${ }^{19}$ Practical considerations, however, impel restriction in this article to briefs filed in the Supreme Court.

\section{The AmICI}

The amici in cases involving the Religion Clauses of the First Amendment may be conveniently divided into two groups: the secular and the religious. By far the greater number of briefs have been filed by the former, and the major groups here are $\mathrm{AJC}, \mathrm{ACLU}$ and $\mathrm{AU} .{ }^{20}$ The religious groups encompass, among others, the NCC, the United States Catholic Conference, and the Synagogue Council of America.

It should be noted that none of the three major secular groups limit their participation in church-state litigation to submission of briefs amicus curiae. All of them actively engage in litigation either as named plaintiffs or in providing counsel for individual plaintiffs, or in both capacities. The form of this participation, however, varies. AU generally lists itself as a plaintiff, usually as the lead plaintiff, along with individual plaintiffs; ACLU conducts the litigation for named individual plaintiffs but does not present itself as a co-plaintiff; AJC conducts litigation through providing counsel for the Committee for Public Education and Religious Liberty of New York (hereinafter, PEARL), or the National Coalition for Public Education and Religious Liberty (hereinafter, National PEARL), coordinating organizations (whose membership also include both AU and ACLU) both of which act primarily as plaintiffs, but occasionally as amici.

\section{A. The Secular Organizations}

1. American Jewish Congress. Quantitatively, at least, the present leader among the secular amici in the area considered in this article appears to be the AJC. ${ }^{21}$ The

17. For an examination of amici participation in church-state cases in all courts, including those below the Supreme Court, see F. Sorauf, The Wall of Separation (1976).

18. See, e.g., brief filed by AJC in Brandon v. Board of Educ. 635 F.2d 971 (2d Cir. 1980) (prayer in public schools); Anderson v. Laird, 437 F.2d 912 (7th Cir. 197I) (military chapel attendance); Pico v. Board of Educ., 638 F.2d 404 (2d Cir. 1980) (school book censorship); Florey v. Sioux Falls School Dist., 619 F.2d 1311 (8th Cir. 1980), cert. denied, 49 U.S.L.W. 3351 (1980) (Christmas in public schools).

19. See, e.g., briefs filed in Margaret S. v. Edwards, 488 F. Supp. 181 (E.D. La. 1980), McRae v. Califano, 491 F. Supp. 630 (E.D.N.Y. 1979), rev'd sub nom. Harris v. McRae, 100 S. Ct. 2671 (1980) (governmental financing of abortions); and McDaniel v. Essex International, 509 F. Supp. 1055 (W.D. Mich 1980) (religious conscience provision in Section 70l(j) of Civil Rights Act of 1964), by organizations affiliated with the Religious Coalition for Abortion Rights (comprised of 27 major Protestant, Jewish, Catholic and other religious organizations).

20. Sorauf, supra note 1 , at 672 .

21. Many briefs submitted in behalf of a number of organizations, particularly those of the Synagogue Council of America and National Community Relations Advisory Council (hereinafter NCRAC), in addition to those submitted by AJC in its own behalf were prepared by the AJC. See, e.g., brief amici in McCollum v. Board of Educ., 333 U.S. 203 (1948). 
organization itself traces its roots back to 1917, and its scope of interest and activities extends far beyond the arena of church-state relations ${ }^{22}$ or even of litigation in general. ${ }^{23}$ It was organized, inter alia . . " to help secure and maintain equality of opportunity, ... to safeguard the civil, political, economic and religious rights of Jews everywhere" and ". . . to help preserve, maintain and extend the democratic way of life."24 Although AJC limits its membership to Jews, the word is used in a cultural or national rather than religious sense. All persons who identify themselves as Jews are eligible for membership, including those who consider themselves atheists or agnostics.

AJC participation as amicus has not been limited to briefs filed in its own name alone, but encompasses briefs which it prepared but which were filed in behalf of the National Community Relations Advisory Council, now known as the National Jewish Community Relations Advisory Council (hereinafter, NJCRAC), a coordinating organization encompassing the $\mathrm{AJC}$, four other national Jewish organizations and 108 Jewish Community Councils throughout the United States. ${ }^{25}$ It has also prepared briefs which were filed jointly with non-Jewish organizations such as the ACLU $^{26}$ and others. ${ }^{27}$

Perhaps without exception, ACJ, unlike ACLU and AU, has not joined in amici briefs within the scope of this article that were prepared by other organizations, or at the very least, in which it has not contributed a major part. The superior quality of its briefs and its leadership in the church-state arena has been generally accepted by scholars and attorneys with familiarity in the field. ${ }^{28}$

A rather novel aspect of amicus briefs submitted by AJC in its own behalf and in behalf of other Jewish organizations has been the invocation, where relevant, of Old Testament and rabbinic sources. Thus, in Stainback v. Mo Hock Ke Lok Po, ${ }^{29}$ a suit challenging the constitutionality of a Hawaii statute forbidding the teaching of foreign languages (Chinese was what was intended) to children before they had passed the fourth grade in public schools, the AJC's brief amicus cited centuries-old

22. See, e.g., brief amici curiae prepared by AJC and submitted in behalf of a number of organizations in NAACP v. Alabama, 357 U.S. 449 (1958), involving freedom of association.

23. The AJC often testifies or submits statements in Congressional hearings on proposed legislation. See, e.g., Treatment of Men and Women Under the Social Security Program: Hearings before the Subcommittee on Social Security of the Committee on Ways and Means, House of Representatives, 95th Cong., 1st Sess. 208 (1979) (statement of American Jewish Congress).

24. Brief amicus curiae of the AJC in Stainback v. Mo Hock Ke Lok Po, 336 U.S. 368 (1949), p. 1. (The appeal was dismissed on jurisdictional grounds.)

25. The national organizations, in addition to AJC, are American Jewish Committee, AntiDefamation League of B'nai B'rith, Jewish Labor Committee, and Jewish War Veterans. See brief amici in Stone v. Graham, 599 S.W.2d 157 (Ky.) rev'd, 101 S. Ct. 192 (1980).

26. E.g., Epperson v. Arkansas, 393 U.S. 97 (1968) (evolution in public schools); Burstyn v. Wilson, 343 U.S. 495 (1952) (film banned for sacrilege).

27. E.g., McDaniel v. Paty, 435 U.S. 618 (1978) (statute disqualifying clergyman from public office). Brief for AJC, ACLU, American Ethical Union, AU, Baptist Joint Committee on Public Affairs, United Methodist Church, National Council of Churches, United Church of Christ, United Presbyterian Church, Unitarian Universalist Association.

28. Sorauf, supra, note 17 at $75-76$.

29. 336 U.S. 368 (1949). 
rabbinic authorities in support of its contention that a ban on teaching children the Hebrew language violates the religious freedom of Jews. ${ }^{30}$

Another illustration is found in Maxwell $v$. Bishop $p^{31}$ and again in Furman $v$. Georgia, ${ }^{32}$ wherein the briefs urging a determination that the death penalty constituted impermissible cruel and unusual punishment quoted the following from the Talmud:

A sanhedrin (high court) which executes a criminal once in seven years is called a "court of destroyers." Rabbi Eliezer ben Azariah states that this is so even if it executes one in every seventy years. Rabbi Tarphon and Rabbi Akiba stated that if they had been members of the sanhedrin no one would ever have been executed. (Rabbi Simon, dissenting, said that would increase murders in Israel.) ${ }^{33}$

2. Americans United. ${ }^{34}$ Protestants and Other Americans United for Separation of Church and State ${ }^{35}$ grew out of a meeting held in Washington in 1947 under the leadership of Joseph M. Dawson, executive director of the Baptist Joint Conference Committee on Public Relations (now Baptist Joint Committee on Public Affairs), undoubtedly motivated by the Supreme Court's decision in Everson $v$. Board of Education, ${ }^{36}$ upholding state subsidization of bus transportation to parochial schools. The Federal Council of Churches was represented at this meeting by its general secretary, Dr. Samuel McCrea Cavert, who, however, stated that the Council could not become a party to the proposed organization because of diversity of opinion within the Council. ${ }^{37}$ Since then $\mathrm{AU}$ and the Federal Council (and its successor NCC) have pretty much gone their separate ways, although they have on a number of occasions filed individual briefs amici on the same side in the same case. $^{38}$

Ensuing from the meeting was a manifesto, issued in 1948, signed by John A. Mackay, president of Princeton Theological Seminary; Edwin McNeill Poteat, president of Colgate-Rochester Divinity School; Methodist Bishop G. Bromley Oxnam;

30. Among the authorities cited in the brief were the Talmud and the commentaries of Maimonides and other scholars of the medieval period. Brief amicus, pp. 13-15 in Stainback v. Mo Hock Ke Lok Po, 336 U.S. 368 (1949).

31. 398 U.S. $262(1970)$

32. 408 U.S. 238 (1972).

33. Talmud, Makkot, Chapter 1 Mishnah 7 (Danby tr.).

34. The description that follows is taken largely from L. Pfeffer, Church State and Freedom 234-35 (rev. ed. 1967). Its accuracy, at least as far as AU is concerned, is attested by reference to it as the source for such a description in AU's brief amicus, footnote 2, in Walz v. Tax Commission, 397 U.S. 664 (1970). See also, A. Stokes \& L. Pfeffer, Church and State in the United States, 346.47 (1964); J. Dawson, Separate Church and State Now, 209-10 (1948); L. Ebersole, Church Lobbying in the Nation's Capital (1951). For an unsympathetic view see L. Creedon \& W. Falcon, United for Separation: An analysis of POAU Assaults on Catholicism (1959).

35. It later changed its name to eliminate the words "Protestants and Other." It did this partly to attract non-protestants, mostly Jewish and non-church affiliated liberals, and partly to counteract the impression that it was an arm of Protestantism, as the National Council of Churches and the Synagogue Council of America were in respect to Protestantism and Judaism respectively.

36. 330 U.S. 1 (1947).

37. EBERSOLE, supra note 34 , at 69 .

38. E.g., Walz v. Tax Commission, 397 U.S. 664 (1970); Worldwide Church of God v. Superior Court, 100 S. Ct. 2974 (1980). 
Louie D. Newton, president of the Southern Baptist Convention; and Charles Clayton Morrison, former editor of The Christian Century. The immediate objectives of the organization were summarized in the manifesto as follows:

1. To enlighten and mobilize public opinion in support of religious liberty as this monumental principle of democracy has been embodied and implemented in the Constitution by the separation of church and state.

2. To resist every attempt by law or the administration of law further to widen the breach in the wall of separation of church and state.

3 . To demand the immediate discontinuance of the ambassadorship to the papal head of the Roman Catholic Church.

4. To work for the repeal of any law now on the statute books of any state which sanctions the granting of aid to church schools from the public school treasury.

5. To invoke the aid of the courts in maintaining the integrity of the Constitution with respect to the separation of church and state, wherever and in whatever form the issue arises, and, specifically, to strive by appropriate constitutional means to secure a reconsideration of the two decisions of the Supreme Court upholding the use of tax funds (a) for providing the pupils of parochial schools with free text books and (b) for the transportation of pupils to parochial schools.

6. To call out and unite all patriotic citizens in a concerted effort to prevent the passage of any law by Congress which allots to church schools any portion of a federal appropriation for education, or which explicitly or implicitly permits the states to make such allotment of federal funds. This purpose in no wise prejudices pro or con the propriety of a federal grant in aid of public education.

7. To give all possible aid to the citizens of any community or state who are seeking to protect their public schools from sectarian domination, or resisting any other assault upon the principle of separation of church and state.

8. In seeking these objectives we are determined to pursue a course that cannot be justly characterized as anti-Catholic, or as motivated by anti-Catholic animus. As Protestants, we can be called anti-Catholic only in the sense in which every Roman Catholic is anti-Protestant. Profound differences separate us in the area of religious faith, but these differences have no relevancy in the pursuit of our objectives as clearly defined in this manifesto. The issue of separation of church and state has arisen in the political area and we propose to meet it there. ${ }^{39}$

3. American Civil Liberties Union. ACLU entered the Supreme Court amicus arena several years before entry by $\mathrm{AJC}$ and $\mathrm{AU}$. The organization was born out of the attacks made on civil liberties in the early days of World War I. Originally a civil liberties bureau in an organization known as American Union Against Militarism, it became independent in 1920 and expanded into ACLU, under the leadership of Roger Baldwin, who remained its director until 1950. Its submission of briefs amicus curiae in the Jehovah's Witnesses cases grew out of the fact that the issue in those cases was considered, as late as West Virginia State Board of Education v. Barnette, ${ }^{40}$ to be primarily freedom of speech rather than of religion. However, in 1947, it expanded its area of concern to establishment litigation by filing an amicus brief in Everson v. Board of Education, ${ }^{41}$ supporting the plaintiffs' position against state financing of transportation to parochial schools. Today its status as by far the

39. Pfeffer, supra note 34 , at 234-35.

40. 319 U.S. 624 (1943).

41. 330 U.S. 1 (1947). 
nation's leading defender of civil liberties ${ }^{42}$ is hardly questioned by its foes no less than by its friends.

The ACLU, like AJC and AU, recognized the limitations of amicus intervention. In 1961 its then director wrote:

The ACLU traditionally has appeared in key cases as amicus curiae. We are not a general legal defense agency and have felt that we could be most effective by highlighting civil liberties issues on the appellate level, once the facts have been established by evidence in the trial courts. This approach has certain obvious disadvantages in that we cannot control the method of production of evidence and thus the establishment of an adequate appeal record in the trial courts.

We have not sought test cases, although some of them have come our way. ${ }^{43}$

The 1970 Guide to ACLU Litigation, however, noted that "although the Union formerly did most of its legal work in an amicus curiae capacity, in recent years direct representation has come to play an increasingly important role for both the National organization and its affiliates." 44 Today, there appears to be something of a division of jurisdiction with ACLU: party participation is largely through local affiliates, i.e., state and city CLU's; amicus intervention is generally the responsibility of the national organization, at least in the forum which defines scope of this article, i.e., the Supreme Court.

4. Others. As previously noted, the AJCommittee filed a brief amicus as early as 1925 in Pierce $v$. Society of Sisters. ${ }^{45}$ Along with the ADL and other national and local Jewish organizations, it formed the National Community Relations Advisory Council (NCRAC), which filed an amicus brief in 1948 in McCollum $\%$ Board of Education. ${ }^{46}$ Thereafter, both it and the ADL withdrew from the NCRAC (because they objected to the assignment of all amicus briefs to $\mathrm{AJC})^{47}$ and along with it filed briefs in Engel v. Vitale, ${ }^{48}$ Abington School District v. Schempp, ${ }^{49}$ and other cases. Later, however, both organizations accepted the continued assignment of drafting briefs amicus to AJC and returned to the NCRAC. The AJCommittee did not thereafter file amicus briefs in the area considered in this article, but the ADL has on several occasions filed briefs jointly with COLPA.

While largely though not exclusively Catholic in its membership, Citizens for Educational Freedom, founded in 1959, was not strictly an instrument of the Catholic Church; among its members were Lutherans, Dutch Reformed, and Orthodox Jews (before establishment of COLPA). ${ }^{50}$ As its name indicates, its concern was limited to the field of education, and more specifically to legalization of governmental support of parochial schools. Although it filed briefs amicus in cases

\footnotetext{
42. As distinguished from civil rights, where NAACP occupies the equivalent status.
43. Quoted in Sorauf, supra note 17 , at 64 .

44. Id., at 65 .

45. 268 U.S. $510(1925)$.

46. 333 U.S. 203 (1948) (religious instruction in public schools).

47. SoraUf, supra note 17 , at 47 n.16.

48. 370 U.S. 421 (1962) (prayer in public schools).

49. 374 U.S. 203 (1962) (devotional Bible reading in public schools).

50. Sorauf, supra note 17 , at 187-89.
} 
involving this issue, it also sponsored and conducted litigation in that area. Thus, in one case, it brought suit to compel the State of Missouri to provide aid to religious schools on the ground that failure to do so violated both the Free Exercise Clause of the First Amendment and the Equal Protection Clause of the 14th. ${ }^{51}$

Succeeding Citizens for Educational Freedom and generally reflecting the Catholic Church's viewpoint in briefs it files as amicus but not as an agency of the Church is the Catholic League for Religious and Civil Rights, an organization, under the long-time leadership of Virgil C. Blum, S.J., whose national membership is approximately 30,000 nationwide and whose concern (as those of AJC, ACLU and $\mathrm{AU}$ ) extends beyond the field of education. ${ }^{52}$ It describes itself as "a voluntary membership organization dedicated to the defense of the rights of all persons of religion and the education of the public respecting issues of religious freedom.. 53

Governmental agencies, federal, state, and local, often intervene in church-state litigation as amici curiae, although generally their involvement in the cases is as the named defendant or codefendant. ${ }^{54}$ There are, however, many occasions when a governmental body finds it desirable to intervene not as a co-party but as an amicus, ${ }^{55}$ even though it may be a real party in interest in the controversy. One

51. Brusca v. State Board of Education, 332 F. Supp. 275 (E.D. Mo. 1971), affd, 405 U.S. 1050 (1972). See Sorauf, supra note 17, at 189

52. Brief amicus in Worldwide Church of God v. Superior Court, 100 S. Ct. 2974 (1980), p. 2.

53. Id. Note should also be taken of the Center for Constitutional Studies of the University of Notre Dame Law School. In its brief amicus curiae in Brandon v. Board of Education (No. 80-1396, submitted in March, 1981), urging reversal of a decision (635 F.2d 971 [1980], affirming 487 F. Supp. 1219 [1980]) invalidating a program for prayer in a public high school, it describes itself as having been "established in 1977 by the University of Notre Dame to serve as a research institute and to engage in selected litigation affecting the integrity and autonomy of independent institutions of higher education, especially church-related colleges or universities." In a footnote to this, the brief states: "The Advisory Board of the Center for Constitutional Studies is composed of attorneys, college administrators and executives of denominations and religious bodies engaged in education. The ecumenical composition of this Board is reflected in the fact that its members are drawn from the following religious groups or communities of faith: Church of Jesus Christ of Latter-Day Saints (Mormon), Jewish, Lutheran, Mennonite, Roman Catholic, Southern Baptist, United Methodist and United Presbyterian."

In view of the strong opposition to public school prayer by the National Council of Churches, the Baptist Joint Committee on Public Affairs, and all the major Jewish organizations affiliated with the Synagogue Council of America (the latter having submitted a brief amici in the Brandon case urging affirmance of the Court of Appeals decision), it is doubtful that its claim to being "ecumenical" can be sustained.

54. See e.g., Flast v. Cohen, 392 U.S. 83 (1968) (New York City named as co-defendant in suit against the United States challenging grants under Titles I and II of the Elementary and Secondary Education Act of 1965, 79 Stat. 27, 20 U.S.C. $\$ \$ 241 \mathrm{la}$ et seq. and $\$ \S 281$ et seq.)

55. See e.g., Sloan v. Lemon, 413 U.S. 825 (1973); Wheeler v. Barrera, 417 U.S. 402 (1974), both involving amicus briefs by the United States in cases challenging aid to parochial schools. Unlike Sloan, Wheeler concerned a conflict between state law (Missouri) and a federal statute, Title I of the Elementary and Secondary Act of 1965, 20 U.S.C. $\$ \S 241$ a $e t$ seq. Hence the government could have intervened as a party, but preferred to present its views as amicus.

For instances of state intervention as amicus see Everson v. Board of Education, 330 U.S. 1 (1947), wherein attorneys-general for six states submitted briefs in support of state-financed bus transportation to parochial schools; Zorach v. Clauson, 343 U.S. 306 (1952), wherein attorneys-general of eight states submitted briefs supporting the defendants' position on the constitutionality of released time religious education; and Board of Education v. Allen, 392 U.S. 236 (1968), wherein eight state attorneys-general submitted amici briefs supporting constitutionality of furnishing textbooks for use in parochial schools.

For an example of amicus intervention by a local governmental agency, see brief amicus of the Scranton School District in Lemon v. Kurtzman, 403 U.S. 602 (1971). 
example of this is Engel v. Vitale ${ }^{56}$ where the New York State Board of Regents, which had formulated and authorized the "non-sectarian" prayer challenged in the case, chose not to intervene but to present its views in a brief amicus curiae. ${ }^{57}$ There are occasions, too, when members of the United States Congress submit briefs amici supporting the constitutionality of a measure enacted by Congress. ${ }^{58}$

\section{B. Religious Organizations}

1. Protestant. The National Council of Churches of Christ in the United States, which is the major Protestant organization most likely to intervene as amicus in church-state cases, describes itself as a co-operative agency of 32 Protestant and Orthodox religious denominations with an aggregate membership in excess of 40 million, organized exclusively for religious purposes and formed, as stated in its certificate of incorporation, "to promote the application of the law of Christ in every relation of life." ${ }^{59} \mathrm{By}$ this, however, is now meant application of the law of Christ only within the limitations of the constitutional separation of church and state, to the maintenance of which it has committed itself. ${ }^{60}$

Since the early 1960's, the NCC, through its Commission on Religious Liberty (in its Division of Church and Society), headed by Rev. Dean M. Kelley, has begun filing briefs amicus in church-state cases, either by itself or together with likeminded groups, and is now doing this in increasing numbers. ${ }^{61}$

The Baptist Joint Committee on Public Affairs represents the interests of eight cooperating Baptist conventions in the United States having a combined membership of some 27 million. ${ }^{62}$ Founded in 1939, it has represented the Baptist commitment to strict separation of church and state. It was, for instance, one of the first Protestant groups to support the Supreme Court's decisions on prayer in the public schools, ${ }^{63}$ and to oppose constitutional amendments that would overturn them. It played a leading role in the founding of the POAU in 1947, and its director, Joseph M. Dawson, served temporarily as its executive secretary. ${ }^{64}$

In most instances, the Baptist Joint Committee has joined with other organizations as co-signers of amici curiae briefs, ${ }^{65}$ but occasionally, as in Walz $v$. Tax Commission ${ }^{66}$

56. 370 U.S. 421 (1962).

57. Engel v. Vitale, 370 U.S. 421 (1962).

58. An example is the brief submitted by three Representatives and Senators in Rostker v. Goldberg, now pending before the Supreme Court (No. 80-251), supporting the constitutionality of 50 U.S.C. app. $\$ 453, \S 454$ (a) (1976) which requires draft registration only of males. Brief of Congressman L. McDonald, et al.

59. Brief amicus of National Council of Churches in Walz v. Tax Commission, pp. 1-2.

60. Joint Brief Amici of National Council of Churches, Synagogue Council of America, Baptist Joint Committee on Public Affairs, Lutheran Church in America, Association of Evangelical Lutheran Churches, the United Methodist Church, the United Presbyterian Church and the National Association of Evangelicals, in Worldwide Church of God v. California, p. 2.

61. Sorauf, supra note 17 , at 53 .

62. Joint Brief Amici supra note 57 at p. 2.

63. Engel v. Vitale, 370 U.S. 421 (1962); Abington School District v. Schempp, 374 U.S. 203 (1963).

64. Sorauf, supra note 17 , at 52 .

65. E.g., as in Worldwide Church of God v. Superior Court, supra note 52.

66. 397 U.S. 664 (1970). 
and National Labor Relations Board v. Catholic Bishop of Chicago, ${ }^{67}$ it has submitted its own brief. In the latter case, involving a challenge to the application of the National Labor Relations Act to collective bargaining by teachers in parochial schools, it supported the position of the Catholic Church, although generally it would be found on the opposite side in litigation, and for this reason has sometimes been charged with anti-Catholic prejudice by its opponents.

2. Catholic. Among the religious groups the Catholic Church is less likely to intervene as amicus than its Protestant (NCC) and Jewish (Synagogue Council) equivalents. When it does so, it is through the United States Catholic Conference (formerly the National Catholic Welfare Conference). Its status and role is set forth as follows in its amicus curiae brief in Walz $v$. Tax Commission: ${ }^{68}$

Among its responsibilities, USCC is authorized to represent the Catholic people of the United States, speaking through their Bishops on matters of public concern. When deemed appropriate, USCC is authorized to offer its views . . . in Federal and State court litigation touching important interests of the Catholic people of the United States, especially in cases involving constitutional issues turning upon the proper construction of the Fourteenth Amendment, ... as that provision protects the freedoms guaranteed by the religious clauses of the First Amendment. ${ }^{69}$

When it does intervene in litigation as amicus, it does so individually. Unlike the NCC and the Synagogue Council it will not file a joint brief amici with other religious organizations. It refused, because of this policy, to join in the brief submitted by the religious groups to the Supreme Court in Worldwide Church of God v. California. $^{70}$

This does not mean that the Church does not involve itself in litigation. On the contrary, when its interests are at stake, it does so as the real party in interest through intervention as a defendant. It effects this through individual low-income Catholics, providing them with some of the highest paid counsel in the nation, such as Porter Chandler of Davis, Polk and Wardell, in the released-time case of Zorach $v$. Clauson, ${ }^{71}$ and Edward Bennett Williams, in the aid to parochial school case of National PEARL v. Hufstedter (formerly Califano) ${ }^{72}$

3. Jewish. Among the religious groups, the Synagogue Council of America is the most frequent intervenor as amicus curiae, ${ }^{73}$ though not in cases involving aid

67. 440 U.S. 490 (1979).

68. 397 U.S. 664 (1970).

69. Brief, p. 2.

70. $101 \mathrm{~S}$. Ct. 270 (1980). An amicus brief, also urging reversal on free exercise and entanglement grounds, was submitted by the Catholic League for Religious and Civil Rights. It is highly doubtful that this would have been done had the Catholic Church been opposed to this position.

71. 343 U.S. 306 (1952).

72. 101 S. Ct. 55 (1980), dismissing for want of jurisdiction 446 F. Supp. 193 (S.D.N.Y. 1978); 489 F. Supp. 1248 (S.D.N.Y. 1980). The defendant Califano was formerly a member of Williams' firm, Williams, Califano and Connolly, but withdrew from it when he was appointed Secretary of Health, Education and Welfare.

73. Among the many cases in which it has appeared as an amicus are: McCollum $v$. Board of Education, 333 U.S. 203 (1948) (religious instruction in public schools); Abington Township School 
to parochial schools. The reason for this abstention lies in the fact that its rules require unanimity in all its decisions, and in those cases the Orthodox constituents of the Synagogue Council (the Rabbinical Council and the Union of Orthodox Jewish Congregations) strongly favor aid to parochial schools, while the other constituents do not.

It was primarily for this reason that COLPA was formed in 1965. In its motion for leave to file a brief amicus in Walz 2 . Tax Commission ${ }^{74}$ it describes itself as an association organized "to represent the position of the Orthodox Jewish Community in matters of public concern." ${ }^{75}$ In cases involving aid to parochial schools, COLPA works very closely with the Catholic Church, and like it participates in these cases as a real party in interest by providing counsel for nominal intervenors. $^{76}$

\section{III}

Arenas of Amicus Intervention ${ }^{77}$

\section{A. Religion in Public Schools}

The great majority of cases under the Religion Clauses in which amici have entered is the area of education, involving either religious practices in the public schools or aid to religious schools. It is important, however, to repeat here what was suggested earlier in this article, i.e., there is rarely a case involving one of the Religion Clauses that does not at the same time involve the other, and this is true in cases that do not concern education ${ }^{78}$ as well as those which do. Amici, there-

District v. Schempp, 374 U.S. 203 (1948) (Bible reading and prayer in the public schools); Furman v. Georgia, 408 U.S. 238 (1972) (capital punishment); Braunfeld v. Brown, 366 U.S. 599 (1961) (compulsory Sunday closing laws); Sherbert v. Verner, 374 U.S. 398 (1963) (unemployment compensation for Sabbatarians).

74. 397 U.S. $664(1970)$.

75. The constituents of COLPA, along with the Union of Orthodox Jewish Congregations and the Rabbinical Council, are the Union of Orthodox Rabbis, Agudath Israel of America, National Council of Young Israel, Poale Agudath Israel of America, Rabbinical Alliance of America, Religious Zionists of America, and the National Association of Hebrew Day Schools, all Orthodox religious organizations.

76. See e.g., National Coalition for Public Education and Religious Freedom v. Califano, 446 F. Supp. 193 (S.D.N.Y. 1978), 489 F. Supp. 1248 (S.D.N.Y. 1980), appeal dismissed 101 S. Ct. 55 (1980). The close cooperation between COLPA and the Catholic Church is indicated by the fact that a joint motion to affirm this case was made by Edward Bennett Williams and Dennis Rapps, Counsel for COLPA.

77. Space considerations impel limitations in respect to both the number of amicus interventions in cases under the Religion Clauses and the extent of the discussion assigned in each instance. Among the relevant cases in which amici intervened are those involving illegitimacy laws (Levy v. Louisiana, 391 U.S. 68 [1968]); military chapel attendance, (Laird v. Anderson, 466 F. 2d 283, cert. denied, 409 U.S. 1076 [1972]); sacrilege (Burstyn v. Wilson, 343 U.S. 495 [1962]); income tax liability of churches expressing positions on political issues (Christian Echoes National Ministry v. U. S., 414 U.S. 864 [1973], denying certiorari in 470 F.2d 849); zoning restrictions on churches and parochial schools (Diocese of Rochester v. Planning Board, 1 N.Y.2d 508 [1956]); ritual slaughtering of cattle (Jones v. Butts, 419 U.S. 806, affg, 374 F. Supp. 1284 [1974]); compulsory school attendance (Wisconsin v. Yoder, 406 U.S. 205 [1972]); and prohibition of foreign language instruction in religious schools (Stainback v. Poe, 336 U.S. 368 [1956]).

78. See e.g., Kedroff v. St. Nicholas Cathedral, 344 U.S. 94 (1952). The decision in this case, involving the extent to which a court may pass upon intra-church disputes under the Supreme Court's "hands-off" doctrine, was based largely upon the Free Exercise Clause, although it also held that judicial 
fore, as well as parties, are likely to ground their briefs on both claims, emphasizing one or the other, depending upon the specific factual situation. ${ }^{79}$ However, in aid to education cases, the amici place major emphasis upon the Establishment Clause, as do the parties and the Court.

In cases challenging religion in the public schools the positions of ACLU, AU, AJC, the Synagogue Council and the other Jewish organizations (including the Orthodox) are identical; all oppose practices such as, among others, religious instruction within public schools, prayer recitation, devotional Bible reading, hymn singing, posting of the Ten Commandments in public schools, and religious baccalaureate exercises. ${ }^{80}$ The Orthodox Jewish organizations, and some Protestant groups, however, do not join the others in opposing public school credit for off-premise religious instruction.

Although the NCC has expressed strong opposition to proposed constitutional amendments or bills aimed at restoring prayer to the public schools in Congressional hearings on the issue ${ }^{81}$ it does not frequently participate in litigation, through amicus briefs or otherwise. ${ }^{82}$ The explanation may be a practical one; unlike the ACLU, AU and the Jewish organizations, the NCC did not and does not have a staff of full-time or even part-time salaried lawyers to draft briefs. (Neither does the Synagogue Council, but it has available to it and consistently utilizes the services of the AJC legal staff.) Recently, however, its amicus participation has become more frequent, partly, as previously noted, because of the activism of Dean Kelley, and partly because it has adopted the practice of the Synagogue Council of joining in briefs drafted by attorneys for other organizations. ${ }^{83}$

The previous position of the Catholic Church on the subject of religion in the public schools changed dramatically after McCollum $v$. Board of Education ${ }^{84}$ came to the Supreme Court in 1948. In the century preceding that decision the Church was consistently opposed to religious teachings and practices in the public schools; indeed it was practically the only opponent. The reason was quite simple; its parochial school system was in its initial period of slow development. As a result,

intervention "violates our rule of separation between church and state." Id., at 110 . But see M. HowE, The Garden and The Wilderness 90 (1965), asserting that only Free Exercise was the basis of the Court's decision.

79. See e.g., brief amici of American Ethical Union and others in Harris v, McRae, 100 S. Ct. 2671 (1980); brief amici of National Council of Churches and others in Worldwide Church of God v. Superior Court, 100 S. Ct. 2974 (1980).

80. The cases in which some or all of the organizations filed amicus briefs include: McCollum v. Board of Education, 333 U.S. 203 (1948) (religious instruction); Engel v. Vitale, 370 U.S. 421 (1962) (school prayer); Abington Township School District v. Schempp, 374 U.S. 203 (1963) (Bible reading in school); Tudor v. Board of Education, 14 N.J. 31, 100 A.2d 897 (1953), cert. denied, 348 U.S. 816 (1954) (Gideon Bible distribution); Stone v. Graham, 599 S.W. 2d 157 (Ky. 1980), rev'd 101 S. Ct. 192 (1980) (Ten Commandments). The ACLU, the AJC and the other Jewish organizations did not file an amici brief in Zorach v. Clauson, 343 U.S. 306 (1952), since they sponsored the suit and their counsel represented the plaintiffs.

81. E.g., 1980 Hearings on bills relating to prayer in public school (S. 450 and S. 210).

82. In the 67 church-state cases covering the period surveyed in SoRAuF, supra note 17, 1951-1971, the NCC filed an amicus brief only in Walz. Sorauf, supra note 17 at 53 .

83. E.g., as in Worldwide Church of God v. Superior Court, 190 S. Ct. 2974 (1980).

84. 333 U.S. 203 (1948). 
the great majority of Catholic children attended public schools, where Protestant influence was a universal and daily reality, manifesting itself through religious instruction, prayer recitation, Bible reading, hymn singing and other religious activities, all of which were Protestant-oriented but participation in which violated Catholic canon law. In 1840, early in the history of compulsory school attendance statutes, the Catholic Church Provincial Council in Baltimore imposed on priests the responsibility of seeing to it that Catholic children did not participate in Protestant instruction and practices and to use their influence to prevent the introduction of these practices into the school system. ${ }^{85}$

It is hardly surprising, therefore, that before $M c$ Collum, practically every suit challenging religious practices in the public schools was brought by Catholic parents. ${ }^{86}$ As late as 1953 Catholic parents joined Jewish parents in a suit challenging the distribution of the (Protestant) Gideon Bible in the public schools, but during the course of that litigation the Catholic parents, who had originally agreed to participate after consultation with their priest, later withdrew from the suit, manifesting the change of position on the part of the Church. ${ }^{87}$

Since 1948 the Church no longer opposes public school involvement in religious practices. On the contrary, along with some evangelical groups such as those that during the 1980 Presidential campaign called themselves the Moral Majority, it strongly favored the return of prayer to the public schools. But, as in other instances, particularly where the issue before the Court was aid to parochial schools, it expressed its position in the Court not primarily through amicus briefs but by intervention as codefendants through individual Catholics. ${ }^{88}$

In the first prayer case to be decided by the Court, Engel $v$. Vitale, ${ }^{89}$ the Church's de facto intervention was manifested by Porter Chandler's appearance as counsel for the intervening Catholic parents. ${ }^{90}$ Its response to the Court's decision is typified by the statement of Cardinal Spellman of New York: "I am shocked and frightened that the Supreme Court has declared unconstitutional a simple and voluntary declaration of belief in God by public school children. The decision strikes at the very heart of the Godly tradition in which American children have so long been raised." 91

\section{B. Aid to Parochial Schools}

The direct intervention by the Catholic Church in litigation involving aid to parochial schools effected by providing counsel to parents of children attending the

85. Pfeffer, supra note 34 , at 335 .

86. The earliest reported decision appears to be Donahoe v. Richards, 38 Me. 376 (1854). For fuller discussion, see Pfeffer, supra note 34, at 436 et seq.

87. Tudor v. Board of Education, 14 N.J. 31, 100 A.2d 857 (1953), cert. denied, 348 U.S. 816 (1954). (1954).

88. E.g., Committee for Public Education and Religious Liberty v. Nyquist, 413 U.S. 756 (1973).

89. 370 U.S. 421 (1962). The prayer read: "Almighty God, we acknowledge our dependence upon

Thee, and we beg Thy blessings upon us, our parents, our teachers and our Country." Id., at 422 .

90. Cf. text, supra, at note 71 .

91. Pfeffer, supra note 34 at 467. 
schools, is entirely appropriate, even more so than in the earlier cases involving religion in public schools, since in the aid to parochial schools cases today it is the Church that is the real party in interest. ${ }^{92}$

There has been an instance, however, when, in a realistic sense, the Church represented both the litigants and amici in the same lawsuit. Although that case, NLRB $v$. Catholic Bishop of Chicago ${ }^{93}$ did not involve aid to parochial schools, its relevance to the subject of aid to parochial schools will be indicated shortly.

The appellees in the case were the dioceses of Chicago and Fort Wayne-South Bend, but after the suit was started, another was brought by the Archdiocese of Los Angeles (Cardinal Timothy Manning, a Corporation Sole) ${ }^{94}$ for judicial review of an NLRB order presenting an issue identical with the one in Catholic Bishop. Unable to participate as a party in that appeal inasmuch as the Court of Appeals had not yet decided their own case, counsel for the Los Angeles Diocese submitted an amicus brief sub nom. "Brief of Certain Catholic High Schools in the Archdiocese of Los Angeles and the Diocese of Orange."

In both cases the gravamen of the complaint was that the Board erred in distinguishing among institutions that were "completely religious" (e.g., a cathedral and its employees) on the one hand, and those (e.g., parochial schools) that were not "completely religious" or were not "religious institutions intimately involved with the Catholic Church," and in deciding to exercise jurisdiction only in respect to the latter organization. The Board, the amicus brief asserted, violated the First Amendment in taking jurisdiction of the controversy because (1) it would thereby improperly entangle governmental authority with the essential religious functions of the Catholic High School, and (2) it would improperly interfere with the school's free exercise of religion.

The amicus brief, it should be noted, might have been limited to the issue of legislative intent and have argued, as was urged successfully in the Catholic Bishop appeal, that it was not the intent of Congress to make a distinction among institutions that were or were not "completely religious" or between those that were or were not "intimately involved with the Catholic Church." Or, the brief might have been limited to the Free Exercise point, asserting (as was asserted in the amicus

92. This was manifested in Committee for Public Education and Religious Liberty (PEARL) v. Califano. At the opening of the trial Edward Bennett Williams made the following statement to the court:

Mr. Williams: Your Honor, with the agreement of my co-counsel for other defendants, I am going to make the first opening statement and try to cover our position, factually and legally, for your Honor and my brothers and sisters at the table will supplement for their respective clients if they wish to add to what I have to say. Transcript of Record in National Coalition for Public Education and Religious Freedom v. Califano pp. 8-9.

Mr. Williams then presented an opening statement of 25 pages. Counsel for the Government followed with an opening statement covering one page; the opening statement of the defendant New York City Board of Education covered three pages, and that of counsel for intervening Jewish defendants, one paragraph.

The direct questioning for all defendants was conducted by Mr. Williams. Transcript of Record, pp. $65 \cdot 156$.

93. 99 S. Ct. 1313 (1979).

94. 223 N.L.R.B. 1218 (1976). 
brief of the Catholic Legal Society through its division, the Center for Law and Religious Freedom) that the Board could not prove a compelling interest or grave need to justify governmental regulation of collective bargaining within parochial schools.

Counsel for the Los Angeles School chose not to so limit their brief in Catholic Bishop, but instead to assert as the second point in their brief that NLRB intervention would effect unconstitutional entanglement in violation of the Establishment Clause. The amicus brief in support of the church's position presented by the Baptist Joint Committee faced no difficulty in arguing both the Establishment and the Free Exercise aspects since in its own behalf and as a constituent of both $\mathrm{AU}$ and of the National PEARL it had consistently invoked the Establishment Clause as a barrier to governmental aid to parochial schools.

Counsel for the Los Angeles Church did not enjoy this option in view of the Catholic Church's strong support of aid to parochial schools. Hence, in submitting their two-point brief in Catholic Bishop it found itself in the unenviable but unavoidable position of invoking the Supreme Court's holding in Lemon v. Kurtzman ${ }^{95}$ that entanglement of church and state in governmental subsidization of the secular aspects of parochial school instruction would violate the Establishment Clause.

In its brief amicus in Catholic Bishop, the American Federation of Teachers, supporting the NLRB, recognized the entanglement difficulty and sought to meet it by asserting that

no impermissible entanglement has been demonstrated. The Board's limited involvement in protecting the rights of the employees does not require an involvement in the legitimate religious prerogatives of the Church. Its role in the schools is certainly less pervasive than other forms of governmental involvement which have been imposed or voluntarily undertaken by the employers. The speculative and hypothetical examples of possible conflict in unfair labor practice proceedings may present questions of interest for legal scholars, but they are not now ripe for adjudication and quite possibly will never require adjudication.

The Los Angeles Church brief, on the other hand, asserted that Lemon $v$. Kurtzman $^{96}$ was not distinguishable, and that the Court's conclusion therein that "religious formation is not confined to a religion course or a single subject," necessitated the same determination of entanglement as in Catholic Bishop. ${ }^{97}$ The

95. 403 U.S. 602 (1971).

96. Id.

97. The brief amicus of the Los Angeles Church reads in part (at p. 7) as follows:

The goal of education at the Schools is to make each individual aware that the religious dimensions of his or her life applies every hour of the day and every day of the year. It is the practice at all the Schools to permeate secular courses and all aspects of school life with Catholic teachings and values. As one of the Union witnesses testified, the "subliminal religious example provided by the lay teacher does permeate every secular course." It is the responsibility of teachers, lay as well as religious, at every Catholic high school to permeate every course and every other activity in which they are involved with the Catholic philosophy, faith, and morals. One witness testified as to at least three ways in which teachers of subjects like physics or chemistry impart religious formation to students.

In short, religious purpose dominates all activity, curricula, and educational techniques of the Schools. As in Lemon, these Schools are an integral part of the religious mission of the Catholic Church since these Schools are "a powerful vehicle of transmitting the Catholic Faith 
Court, if only by dictum, practically adopted that argument. It did so by citing and relying not only upon Lemon $v$. Kurtzman ${ }^{98}$ but also upon Meek v. Pittenger ${ }^{99}$ and quoting therefrom the statement that "Whether the subject is 'remedial reading', 'advanced reading' or simply 'reading', a teacher remains a teacher, and the danger that religious doctrine will be intertwined with secular instruction persists." ${ }^{100}$

The issue of entanglement (as well as advancement) is certain to come to the Supreme Court, sooner or later, in a challenge to Title I of the Elementary and Secondary Act of 1965; or it may come up in an appeal from the decision of the Court of Appeals in Decker v. U. S. Department of Labor, ${ }^{101}$ or a similar case, holding violative of the Establishment Clause a provision in the Comprehensive Employment Training Act of 1973 (CETA) $)^{102}$ for the payment of federal funds to subsidize public service employment positions in elementary or secondary schools operated by religious or sectarian institutions; or it may come up in some other way. However the issue is bound to come to the Supreme Court, and when it does, it will be difficult for the Church to take the position that Lemon r. Kurtzman ${ }^{103}$ and Meek $v$. Pittenger ${ }^{104}$ were incorrectly decided and should be overruled.

\section{Contraception}

The frequent interchangeability of party and amicus indicated in the cases involving religion and education is manifest too in those passing upon the prevention of birth. The first of these, Tileston v. Ullman, ${ }^{105}$ reached the Supreme Court in 1943, when laws forbidding the sale of contraceptives, ubiquitous as they were, had pretty much become dead letter statutes.

The religious origin of anti-conception and abortion prohibitions (whether common law or statutory) is hardly open to question. ${ }^{106}$ That fact would be irrelevant to litigation in England involving either birth control or abortion, since non-establishment is not part of English law. It would, however, seem to be not merely relevant but could well be critically significant in challenges invoking not only the Establishment but also to a lesser extent the Free Exercise Clause.

Catholic doctrine forbids contraception as contrary both to revealed and natural law. ${ }^{107}$ This view is not shared by Protestantism or Judaism; but the orthodox in

to the next generation." Lemon v. Kurtzman, 403 U.S. at 616 . The integration of religious truth and values with life distinguishes the Catholic school from all other schools, particularly the public schools over which the Board has no jurisdication. (Emphasis added.)

98. 403 U.S. 602 (1971).

99. 421 U.S. 349 (1975).

100. Id. at 370 .

101. - F.2d. - (7th Cir. 1980).

102. 29 U.S.C. $\S \S 853-889$ (1980).

103. 403 U.S. 602 (1971).

104. 421 U.S. 349 (1975).

105. 318 U.S. 44 (1943).

106. In respect to contraception, see Genesis 38:9. In respect to abortion, see Exodus 20:13; Deuteronom $5: 17$.

107. L. Pfeffer, Creeds in Competition 116 (1958), quoting Pius XI: "Any use whatsoever of marriage exercised in such a way that the act is deliberately frustrated in its natural power to generate life is an offense against the law of God and of nature." 
both agree that the practice is sinful, or, at the very least, immoral, and it was the Protestant influence that wrote the prohibition into secular law. ${ }^{108}$ Both Protestantism and Judaism, however, were able to adopt their religious convictions to the reality of American life. In Catholicism the evolution has been more difficult; even today, the Vatican from time to time publicly declares the sinfulness of contraception.

In Tileston v. Ullman ${ }^{109}$ the Court found a procedural defect enabling it to avoid passing upon constitutionality; it held that while persons deprived of their claimed right to use contraceptives might have standing to sue, physicians who prescribed them did not-a determination difficult to reconcile with its holding in Pierce $v$. Society of Sisters ${ }^{10}$ that parochial school teachers had standing to challenge a law requiring parents to send their children exclusively to public schools. A second effort was made, almost two decades later, in Poe v. Ullman. "1l Here, the standing issue could not be invoked to avoid decision on the merits, inasmuch as two married couples joined a Yale Medical School's gynecology professor as co-plaintiffs. This time the Court was able to avoid deciding on the merits by finding that the challenged Connecticut law was not being enforced so that there was before it no real case or controversy-a determination again difficult to reconcile with its later holding in Epperson v. Arkansas. ${ }^{112}$

Trying a third time, another Yale gynecology professor and the executive director of the Planned Parenthood League succeeded in getting themselves arrested (and fined $\$ 100$ ) for aiding and abetting the sale and use of contraceptives. It is difficult to believe that, had the Court wanted to do so, it could not have again avoided passing upon the merits, perhaps by recognizing that there was no real case or controversy before it and that the situation had much of the aspects of a feigned case. This time, however, the Court elected to decide the case upon the merits, and issued its landmark decision in Griswold $v$. Connecticut. ${ }^{113}$

What is significant in this case (and its successor, Eisenstadt v. Baird), ${ }^{114}$ insofar as this article is concerned, is that in each of them the Court was able to avoid addressing itself to the real controversy-the religious basis of anti-contraception laws and the relevancy of the Establishment and Free Exercise Clauses. It did this in major part by reading the right of privacy into the Bill of Rights, primarily into the First Amendment's guarantee of freedom of association (itself read into the First Amendment by NAACP ข. Alabama ${ }^{115}$ ).

Also implicated were rights, no less seemingly remote, under the Third Amendment's prohibition of quartering of soldiers (which seems never before then to have been cited in a Supreme Court opinion), the Fourth Amendment protection against

108. Id., at 114 .

109. 318 U.S. 44 (1943).

110. 268 U.S. 510 (1925).

111. 367 U.S. 497 (1961).

112. 393 U.S. 97 (1968).

113. 381 U.S. 479 (1965).

114. 405 U.S. 438 (1972).

115. 357 U.S. 449 (1958). 
unreasonable searches and seizures, the Fifth Amendment's guarantee against self-incrimination, and the rarely invoked Ninth Amendment. In short, everything conceivably relevant was invoked except the Religion Clauses, resulting in something like playing Hamlet without the Dane.

Nevertheless, in both Griswold and Eisenstadt the question of religion was in a real though disguised sense brought into the litigation, implicitly rather than expressly, and in support of rather than in opposition to the challenged statute. In both the statutes were defended, inter alia, on the grounds of morality, that is, that the legislative purpose was to protect morals through regulating the private lives of single persons. While that argument would be relevant to intercourse between single persons, as was the case in Eisenstadt, it was obviously irrelevant in Griswold, which involved married couples and was adjudicated not on the ground of morality (i.e., as a violation of natural law) but of marital privacy.

Only in Poe v. Ullman ${ }^{116}$ was the suit brought by those who could technically be deemed the real parties in interest, a couple who claimed that the statute interfered with their marital right. In all the cases, including Poe where the couple were realistically only nominal plaintiffs; the litigation was conceived and conducted by organizations which would ordinarily be amici, thus witnessing the frequent interchangeability of party and amicus.

\section{Abortion}

The struggle, legislative as well as judicial, centering about abortion and its funding presents another instance in which realistically it is often difficult to distinguish between the litigants and the amici as to which are the real parties in interest. Nominally, as in Poelker v. Doe, ${ }^{117}$ Margaret S. v. Edwards, ${ }^{118}$ and Harris v. $M c R a e,{ }^{19}$ these were on the one hand the women seeking the abortion and, on the other, a governmental body opposing it. In reality, however, the contestants were the ACLU (through its Center for Constitutional Rights) and other pro-abortion organizations on one side, and anti-abortionists such as the Catholics and other religious groups (e.g., the Mormons and Orthodox Jews) on the other.

Religious organizations, Protestant and non-Orthodox (Reform and Conservative) Jewish organizations associated with the Religious Coalition for Abortion Rights filed amici briefs in each of these cases. ${ }^{120}$ The briefs argued that governmental restrictions on abortion, beyond those sanctioned in Roe $v$. Wade, ${ }^{12 l}$ violated

116. 367 U.S. 497 (1961).

117. 432 U.S. 519 (1977).

118. 488 F. Supp. 181 (E.D. La. 1980).

119. 448 U.S. 297 (1980).

120. The organizations included American Ethical Union, American Humanist Association, United Methodist Church, Catholics for a Free Choice, Church of the Brethren, Disciples of Christ, Unitarian Universalists Federation, Union of American Hebrew Congregations, and Young Women's Christian Association. For the non-Orthodox position that the Jewish religion does not forbid all abortions even where the life of the woman is not in danger, see D. Feldman, Marital Relations, Birth Control and Abortion in Jewish Law (1974), chapter 15.

121. 410 U.S. $113(1973)$. 
both the Establishment and Free Exercise Clauses. They violated the former because they preferred those religions that forbid abortion over those that do not, their purpose was religious, and their effect was to advance the religions that forbid abortions and inhibit those that do not. They violate the Free Exercise Clause since they impose the inhibitions of religions that deem abortions sinful upon persons whose religious beliefs do not exclude abortion procedures, and particularly upon those whose religious beliefs dictate that access to the procedure on the part of the poor be equal to that of the well-to-do.

In respect to the religious issue Professor Laurence Tribe, in his American Constitutional Law (1978) states:

Suggestions have been advanced that the interest in fetal life is intrinsically religious, or at least that the inescapable involvement of religious groups in the debate over abortion rendered the subject inappropriate for political resolution and hence proper only for decision by the woman herself. But, on reflection, that view appears to give too little weight to the value of allowing religious groups freely to express their convictions in the political process, underestimates the power of moral convictions unattached to religious beliefs on this issue, and makes the unrealistic assumption that a constitutional ruling could somehow disentangle religion from future public debate on the question. ${ }^{22}$

The question, however, is not the right of religious groups to express their convictions on this or any other issue: the First Amendment's guarantees of freedom of speech and petition take care of that. The question is whether in determining if a statute is unconstitutional because its purpose or effect is to advance religion, the Court may or may not consider the role played by religion in the enactment of the statute. As the Court said in McGowan v. Maryland:

We do not hold that ... legislation may not be a violation of the "Establishment" Clause if it can be demonstrated that its purpose-evidenced either on the face of the legislation, in conjunction with its legislative history, or in its operative effect-is to use the State's coercive power to aid religion. ${ }^{123}$ [Emphasis added.]

Returning to the amici brief in Poelker $v$. Doe,${ }^{124}$ it should be noted that the case manifested an unusual but by no means unprecedented situation, ${ }^{125}$ that of a party adopting the argument of an amicus rather than the reverse. The contentions there set forth in the amici brief were adopted and made part of the plaintiffappellees' brief (and also in the amici brief) in Harris v. McRae. ${ }^{126}$ Unlike the situation in Poelker, the Court could therefore not ignore the contentions but had to pass upon them. Realistically considered, the result was the same: the establishment argument was rejected on the merits and with little discussion; the free exercise argument was rejected on the ground that plaintiffs had not alleged or established that their own religious conscience mandated resource to abortion, but the tone of the rejection manifested a view that the argument was no more meritorious than the one based on the establishment claim. ${ }^{127}$

\footnotetext{
122. At 928 (footnotes omitted).

123. 366 U.S. 420,453 (1961).

124. 432 U.S. 519 (1977).

125. E.g., NAACP v. Alabama, 357 U.S. 449 (1958).

126. 448 U.S. 297 (1980).

127. Id., at $2689-90$.
} 


\section{E. Sunday Laws}

As indicated earlier in this article the Supreme Court now recognizes a dichotomy between the Establishment and Free Exercise Clauses and the possibility that in a particular situation the two may present contradictory resolutions of a particular fact situation. In most cases, however, the duality will simply be that of differing approaches to the same determination. A law, for example, which forces a person to go to or remain away from church obviously violates the Free Exercise Clause, but it is also forbidden by the Establishment Clause, ${ }^{128}$ since it aids or inhibits religion. $^{129}$

Sunday closing laws illustrate not only this occasional dichotomy but also the frequent interchangeability of party and amicus. In Friedman $v . N e w$ York $^{,{ }^{130}}$ the Supreme Court rejected without opinion an appeal, conducted by AJC counsel, from the conviction of two Orthodox Jewish merchants who kept their stores open on Sundays in violation of the State's compulsory closing laws. A decade later, a brief amici prepared by AJC and submitted in behalf of the Synagogue Council and the constituents of the NCRAC, presented the same arguments that had proved unsuccessful in Friedman: that the statute violated the Establishment Clause as defined in Everson and the later aid to religion cases, the Free Exercise Clause insofar as it was applied to Sabbatarians, the Equal Protection Clause insofar as the statute on its face was discriminatory in that it irrationally exempted some businesses (e.g., professional sports, motion picture houses and vendors of gas for motor vehicles), and the same Clause in that local police in enforcing the laws against occupations that were encompassed in it acted irrationally, often allowing larger businesses to remain open on Sundays while issuing summons against smaller, family-owned stores.

The free exercise issue was asserted by the parties and the amici in two of the four Sunday Closing Laws cases decided in 1961, Gallagher v. Crown Kosher Super Market $^{131}$ and Braunfeld $v$. Brown ${ }^{132}$ (it was not relevant in the other two cases, McGowan v. Maryland ${ }^{133}$ and Two Guys from Harrison-Allentown v. McGinley, ${ }^{134}$ since these involved stores that were open seven days each week). The argument as presented in the amici brief was that the Sunday laws in issue restricted the religious liberty of merchants whose conscience required them to observe a day other than Sunday as their religious day of rest. It urged further that it was unrealistic to assert that the laws do not compel Sabbatarians to violate their Sabbath inasmuch as they were at liberty to keep their stores closed on Saturday, since requiring Sabbatarians to abstain from engaging in their trade or business for two days each week whereas their Sunday-observing competitors could abstain from

128. See Everson v. Board of Educ., 330 U.S. 1, 15 (1947).

129. See Wolman v. Walter, 433 U.S. 229 (1977).

130. 341 U.S. 907 (1951), dismissing appeal from 302 N.Y. 75, 96 N.E.2d 184 (1950).

131. 366 U.S. 617 (1961).

132. 366 U.S. 599 (1961).

133. 366 U.S. 420 (1961),

134. 366 U.S. $582(1961)$. 
business only one day imposed upon the former substantial competitive disadvantage and thus penalized them for adhering to their religious beliefs.

The Court was not persuaded. With Justice Douglas, Brennan, and Stewart dissenting (Justice Douglas was of the view that all Sunday closing laws were religious laws and should therefore be declared unconstitutional even in respect to non-Sabbatarians), the Court held that non-exemption of Sabbatarians did not invalidate Sunday laws since the difficulty of enforcing such laws if Sabbatarians were exempted justified uniformity and non-exemption.

Yet, it cannot be said that the amici brief submitted by the Jewish organizations had no effect on the Court's majority. Two years after the decision was handed down, the Court held, in Sherbert $v$. Verner, ${ }^{135}$ that a state violated the Free Exercise Clause in denying unemployment compensation benefits to a Seventh Day Adventist who rejected a job offer that required her to work on Saturdays in violation of her religious conscience. Here, too, the Synagogue Council submitted a brief amicus arguing (as did the appellant) that Braunfeld and Crown Kosher were distinguishable. The majority opinion in Sherbert, written by Justice Brennan, a dissenter in Braunfeld and Crown Kosher, sought to distinguish those decisions. Another dissenter, Justice Stewart, issued a concurring opinion, stating that the cases were indistinguishable and that the Court should be frank enough to state what it was actually doing, i.e., overruling the earlier decisions. Justice Harland and White agreed with Justice Stewart on indistinguishability but dissented because they did not believe those decisions should be overruled.

It is difficult to avoid this conclusion of Justices Stewart, Harlan, and White in Sherbert; and it is a fair assumption that the amici briefs submitted in both Braunf eld-Crown Kosher and in Sherbert had a significant effect on the Court's disposition of the latter case. It should be noted that the Court has recently decided the case of Thomas $v$. Review Board, ${ }^{136}$ involving the question whether Sherbert, if not overruled, impels a determination that states violate the Free Exercise Clause in denying unemployment benefits to a Jehovah's Witness who by reason of religious conscience refuses to work in a plant manufacturing weapons for war. Amici briefs in support of the claimant were filed, one by the Synagogue Council and the AJC, and the other by the Jewish Peace Fellowship and the Fellowship of Reconciliation, both of which rely heavily on Sherbert. The Court held Sherbert determinative of the question presented to it. ${ }^{137}$

\section{IV \\ Functions of Amici Intervention}

\section{A. Reinforcement}

As noted above, ${ }^{138}$ the Supreme Court Rules require that a motion to file a brief amicus must set forth the reasons for believing that the questions of law addressed

135. 374 U.S. 398 (1963).

136. 49 U.S.L.W. 4341 (Apr. 7, 1981).

137. The Thomas case is discussed in notes 87-88 of Serritella, Tangling with Entanglement: Toward a Constitutional Evaluation of Church-State Contacts, 44:2 LAw \& ConTeMP. Prob. Spring 1981, at 155-56.

138. See p. 85 above. 
therein will not be adequately presented by the parties. This appears to be quite reasonable, since the submitter represents himself to be a friend of the court, rather than of any of the parties. During the fifties when the Court manifested a decided lack of sympathy towards amici briefs and rarely granted motions for leave to submit, it presumably was generally unconvinced that the movants had anything original to offer.

This antipathy placed the decision on submissibility in the hands of counsel for the parties. Occasionally, a trade-off resulted; counsel for one of the parties would condition his consent on his adversary's consenting to briefs supporting the other side of the controversy. Often, however, one or the other withheld consent thus requiring procedure by usually unsuccessful motion.

The Court's present policy of almost uniformly granting motion for leave to submit $^{139}$ indicates a recognition that strict enforcement of the inadequacy requirement could not, as a practical matter, be met so long as its rules required that the amicus brief must be filed, and the motion for leave to file must be made within the same period in which the party supported must file his brief. Because of this, counsel for the amicus must generally prepare his brief without having seen the brief of the party he is supporting, and while conferences between himself and the party's counsel are possible, time pressures and the reluctance of one attorney to allow another to see his brief before it is safely filed lest it be plagiarized (the ideas in legal briefs are not copyrightable) makes these an infrequent rather than a usual practice.

The net result of this development is that the primary function of amici briefs today is reinforcement by repetition of the same arguments that are presented in the respective party briefs. It is not to be concluded from this that amici briefs therefore serve no significant purpose in the presentation to the court of a party's position. In the first place, unlike the parties, amici need not argue every point raised in the appeal, but can, and often do, concentrate on one or two particular issues. ${ }^{140}$ In view of the page limitations now imposed by the rules of the Supreme Court upon briefs of parties (as well as amici), ${ }^{141}$ the more intensive treatment of a

139. In Gillette v. U.S., 401 U.S. 439 (1971), a motion for leave to submit a brief amicus, made by an attorney acting for himself alone, stated that "the reason for his submitting [the] brief [was] his concern as an attorney with pending matters involving the same issue, and his attendance at meetings of attorneys likewise concerned." The motion was granted. 400 U.S. 955 (1970).

The opinion in Worldwide Church of God v. Superior Court, 100 S. Ct. 2974 (1980) reads as follows:

Motion of National Council of Churches of Christ, et al, for leave to file a brief, as amici curiae, granted. Motion of American Civil Liberties Union of Southern California, et al. for leave to file a brief, as amici curiae, granted. Motion of Holy Spirit Association for the Unification of World Christianity, et al., for leave to file a brief, as amici curiae, granted. Motion of Church of the Nazarene for leave to file a brief, as amicus curiae, granted. Motion of Catholic League for Religious and Civil Rights for leave to file a brief, as amicus curiae, granted. Petition for writ of certiorari to the Court of Appeal of California, Second Appellate District. June 2, 1980. Denied.

All the amici urged granting the petition for certiorari and reversal of the order appealed from. Only the attorney general urged denial.

140. Cf. brief of American Ethical Union et al., in Harris v. McRae, 448 U.S. 297 (1980), devoted to Establishment and Free Exercise, and appellees' brief which deals also with statutory construction, due process and equal protection.

141. Rule 36 limits amici briefs to 30 pages. By no means uncommon before its adoption was the 
particular point in an amicus brief can be helpful both to the Court and to the party whose position is supported by it.

An example of this can be found in the concurring opinion of Justice Frankfurter in McCollum $v$. Board of Education. ${ }^{142}$ There he referred to the divergence of views expressed in the briefs submitted on behalf of various organizations as amici curiae as in itself suggesting that the movement for religious instruction in the public schools had been a "divisive and not an irenic influence in the community." 143 It must be noted that when this case was decided there were no limitations on the number of pages in briefs either of parties or amici. Nevertheless, the appellants' brief had no reference to the point made by Justice Frankfurter, which was made only in the amicus brief of the Synagogue Council. ("The divisiveness which inevitably results whenever sectarianism enters the public school affects all American children but is particularly harmful to children of minority faiths.") ${ }^{144}$

Secondly, amicus briefs may present a more effective treatment of arguments set forth in the parties' briefs. ${ }^{145}$ Many of the suits brought in the church-state area, initiated by citizens suing as parents or taxpayers, are litigated by lawyers who accept the case on a pro bono basis, and are sometimes motivated at least in part by a rare opportunity to argue a case in the Supreme Court. Even if the would-be plaintiff obtains counsel from a local branch of the ACLU or AU, the latter too may often be a volunteer attorney similarly without prior experience in the subject involved in the litigation. In these situations an amicus brief by an attorney experienced in the area could be of substantial help not only to the party but also to the Court. It is reasonable to believe that when a Supreme Court justice (or his clerk) sees the name of such an attorney on the amicus brief he is likely to read it if for no other reason than to help him in his own research.

Having said this, the fact remains that in a great many cases, probably a majority, the amicus brief adds little if anything that is not adequately covered in the parties' briefs.

\section{B. Introducing New Arguments}

There are, however, occasions in which a brief amicus does more, or something other, than reinforce the arguments set forth in a party's brief. In these instances the amicus may be fulfilling the original and true purpose of amici briefs, that is,

brief submitted by the New Jersey State Council of the Junior Order of United American Mechanics, a fraternal patriotic order, in Doremus v. Board of Education, 342 U.S. 429 (1952). The brief, urging affirmance of the New Jersey supreme court decision upholding Bible reading and prayer recitation in the public schools, was 63 pages in length. (The Court dismissed the appeal for want of jurisdiction.)

142. 333 U.S. 203 (1948).

143. Id., at 228 n. 19 .

144. At p. 2.

145. Although not within scope of subject matter treated in this article, NAACP v. Alabama, 357 U.S. 449 (1958), presents an interesting illustration of this point. After the Court denied the motion for leave to file a brief amici in behalf of the AJC and 13 other organizations, counsel for the NAACP set forth almost verbatim in his reply brief the substance of a point in the rejected brief, that anonymity may serve the purposes of a democratic society and help secure freedom of expression. Amici brief, pp. 33-39. 
acting as a friend of the court in helping it reach a correct decision in the case before it. As noted above, this is what the rules of the Supreme Court purport to mandate in requiring that a motion for leave to file must set forth reasons for believing that the issue addressed will not be adequately presented by the parties.

A case in which the performance by an amicus of this traditional function with effective results is Epperson v. Arkansas. ${ }^{146}$ There a public school teacher brought suit challenging the constitutionality of a statute forbidding instructors in tax-supported schools from teaching any theory that denies the story of Divine Creation of man as taught in the Bible, and to teach instead that man has descended from a lower order of animals.

The gravamen of the suit was that the statute was void for vagueness. The trial court, however, invalidated it as violative of the First Amendment's guarantee of freedom of speech in that it tended "to hinder the quest for knowledge, restrict the freedom to learn, and restrain the freedom to teach." The state supreme court reversed in a short per curiam opinion on the ground that the statute was a valid exercise of the state's power to specify the curriculum in its public schools.

On appeal the United States Supreme Court reversed and declared the statute unconstitutional on the sole ground that it violated the First Amendment's ban on laws respecting an establishment of religion, a claim asserted and argued only in the joint amicus brief of AJC and ACLU.

This, of course, is not the only instance in which an amicus suggested a ground for decision not raised by any of the parties. In Walz $v$. Tax Commision ${ }^{147}$ the NCC asserted a claim that taxation of land used for religious services would violate the Free Exercise Clause. In Poelker v. Doe,${ }^{148}$ as noted earlier, the brief amici submitted by a group of organizations affiliated with the Religious Coalition for Abortion Rights asserted that government prohibition of abortion violated the Religion Clauses. In neither instance were these claims raised by any of the parties, and in both the Court refused to pass upon them. ${ }^{149}$

A case now awaiting decision, St. Martins Evangelical Lutheran Church $v$. South Dakota, ${ }^{150}$ presents another example of an amicus urging a position not treated or not fully treated by the parties. The issue before the Court is the constitutionality of governmental systems (state and federal) of unemployment compensation under which "churches" are exempt from coverage but "church-related" schools are not. A brief amicus submitted by the AJC urges, but does not argue, that the Court should construe the statutes to exclude religious schools and thereby avoid deciding the First Amendment issues, but urges further that should the Court decide otherwise, it should declare the statute unconstitutional. The crux of the brief, however, is the argument that in determining constitutionality no distinction should

146. 393 U.S. 97 (1968).

147. 397 U.S. $664(1970)$.

148. 432 U.S. 519 (1977).

149. The Religion claim was asserted by a party in Harris v. McRae, $100 \mathrm{~S}$. Ct. 2671 (1980), and was considered and rejected by the Court.

150. 1980 Term, No. 80-120. 
be made between "churches" and "church-related" schools and that an effort to apply different rules of constitutionality between them is unwarranted. ${ }^{151}$

Even where the Court's opinion ignores an amicus brief, as is most often the case, or, as sometimes happens, expressly rejects an argument set forth therein, the brief itself may serve an important function in effectuating the ends sought by the amicus. The pro-abortion amici brief filed in Harris $v . M c R a e^{152}$ by the organizations affiliated with the Religious Coalition for Abortion Rights is an example of this. The Coalition reprinted the brief in large numbers for nation-wide distribution. Included is an appendix (but not part of, nor referred to in, the brief submitted to the Court) entitled a "Call to Concern", which sets forth the Coalition's position on governmental restrictions in respect to abortion and the endorsement of that position by a large number of professors in theological and other institutions of higher learning, and by Protestant and Jewish religious organizations. The brief thus served a significant educational purpose even though it failed to persuade the Court.

While it is rare for the Court to adopt and make its own a claim asserted only by an amicus, Epperson $v$. Arkansas ${ }^{153}$ is not the only instance in which it has done this. ${ }^{154}$ But even if it were not so, even if, as in most cases, the Court simply ignores the claim, it may become part of the literature in the subject and ultimately

151. On May 26, 1981, since the above was written, the Supreme Court handed down its decision in this case, holding that the 1976 amendment of the act (Pub. I. $566 \S 115$ (b)(1), 90 Stat. 2670) was not intended to alter the existing exemption of churches and church schools, thereby avoiding the need to decide the constitutional issues. 49 U.S.L.W. 4575 (May 26, 1981).

152. 448 U.S. 297 (1980).

153. 393 U.S. 97 (1968).

154. Mapp v. Ohio, 367 U.S. 643 (1961), originating not under the Religion but under the Speech and Press Clauses, presents a rather startling illustration. There, in an appeal from a conviction for possession of obscene materials, the Court reversed on the ground that the evidence used against the defendant had been obtained in violation of the Fourth Amendment. How this came about appears from footnotes 5 and 6 of Justice Harlan's dissenting opinion (at p. 673:)

5. The appellant's brief did not urge the overruling of Wolf. Indeed it did not even cite the case. The brief of the appellee merely relied on Wolf in support of the State's contention that appellant's conviction was not vitiated by the admission in evidence of the fruits of the alleged unlawful search and seizure by the police. The brief of the American and Ohio Civil Liberties Unions, as amici, did in one short concluding paragraph of its argument "request" the Court ot re-examine and overrule Wolf, but without argumentation. I quote in full this part of their brief:

"This case presents the issue of whether evidence obtained in an illegal search and seizure can constitutionally be used in a State criminal proceeding. We are aware of the view that this Court has taken on this issue in Wolf $v$. Colorado, 338 U.S. 25. It is our purpose by this paragraph to respectfully request that this Court re-examine this issue and conclude that the ordered liberty concept guaranteed to persons by the due process clause of the Fourteenth Amendment necessarily requires that evidence illegally obtained in violation thereof, not be admissible in state criminal proceedings."

6. Counsel for appellant on oral argument, as in his brief, did not urge that Wolf be overruled. Indeed, when pressed by questioning from the bench whether he was not in fact urging us to overrule Wolf, counsel expressly disavowed any such purpose

It is quite evident that the Court had earlier decided to overrule Mapp $v$. Ohio and was waiting for an appropriate occasion to do so. The above three sentences in the ACLU amicus brief addressed to the First Amendment issue furnished the occasion 
influence judicial or legislative action. ${ }^{155}$ In any event, amici cannot predict whether in any particular instance what happened in Epperson will not happen again. Hence, if they have a non-frivolous argument not made by any of the parties, prudence would dictate that they assert it.

\section{Amening}

Another function of amici briefs is what may be called "amening", or "metooing", that is, the submitters make little if any effort to add to what has been presented in the parties' brief, but simply endorse the position of the party they want to prevail. On occasion they may set forth in the interest-of-the-amicus section an impressive description of the submitting church or organization, followed by perhaps two or three pages of argument. Sometimes even the latter is dispensed with and the amicus simply incorporates by reference arguments presented in the brief of the party or of another amicus. ${ }^{156}$

It should not be assumed that such amening briefs serve no purpose or function other than institutional self-aggrandizement. In Walz $v$. Tax Commission ${ }^{157}$ the intervention as amici of religious organizations whose combined memberships exceeded a majority of all Americans, testified to the claim made in the NCC brief that taxation of property used for religious purposes endangered the free exercise of religion. It could not but have had some effect in persuading the members of the Court other than Justice Douglas, that an unfavorable decision would have a primary effect of inhibiting religion, even though the Court chose to base its decision on the mandate of non-entanglement.

In another sense, Walz presents an intriguing variant. There attorneys general for 35 of the states submitted amici briefs. These could hardly be more than amening briefs; it is impossible that they could have added anything substantial to the arguments presented in the parties' briefs.

One might assume that these briefs (unlike those submitted by the religious organization) would urge reversal and a determination that according exemption to church-owned properties violated the Establishment Clause. Were the Court so to hold, the annual incomes of state treasuries would increase by hundreds of millions, if not billions, of dollars. Nevertheless, without exception all of the state amening briefs supported the defendant's position that exemption was not constitutionally impermissible. Without being overly cynical one can suggest that a governor who authorized the submission of a brief in support of Walz's position would

155. See text accompanying footnote 160 infra.

156. In McCollum v. Board of Education, 333 U.S. 203 (1948), the American Ethical Union filed no brief, but presented a motion to the Court, consisting of two paragraphs, the first identifying and describing itself, and the second reading as follows:

"We have read the brief amici curiae fled by the Synagogue Council of America and the National Community Relations Advisory Council. We endorse the views expressed in that brief and respectfully move this Court for leave to adopt this brief as our own."

The motion (designated by the Court as "statement") was granted. 66 S. Ct. 204 (1947).

157. 397 U.S. 664 (1970). 
not long remain in office, and this notwithstanding the fact that the beneficiaries of a pro-Walz decision would have been the great majority of the state's homeowners.

In Pollock v. Farmers' Loan and Trust Company, ${ }^{158}$ the Court recognized the anomaly of deciding a suit between private litigants affecting millions of American taxpayers without hearing the Attorney General, and accordingly invited his intervention. Since in the free exercise cases the attorney for the government, federal or state, is an adversary, representatives of religious bodies should be allowed to present their views at least as amici. Functionally, the congregants are more likely to abide by an adverse decision if they had an opportunity to express their views to the court, even in an amening brief.

Finally, and most important, amici intervention often leads to achievement of the submitters' purpose by legislation, rather than judicial action. The brief amici filed by the Synagogue Council in Braunfeld $v$. Brown ${ }^{159}$ and Gallagher $v$. Crown Kosher Supermarket ${ }^{160}$ undoubtedly led to speedy amendment of Sunday closing laws in Pennsylvania and Massachusetts to exempt Sabbatarians, thus according the very relief the Supreme Court refused to grant.

More recently, Worldwide Church of God v. Superior Court ${ }^{161}$ presented another instance of achievement by legislation of what the Court refused to effect by judicial mandate. Shortly after certiorari was denied, the state legislature adopted an amendment to the relevant statute banning any further entanglement by the state attorney general in the internal affairs of a church, thus effecting the result sought by the Church and the amici. The circumstances surrounding this development present strong evidence that the amici brief submitted to the Supreme Court by the religious groups (a copy of which was received by the governor and every member of the legislature) was a major if not the major cause of the enactment of the measure and its approval by the governor, and this notwithstanding the strong opposition on the part of the attorney general. Although the Catholic Church, by reason of individual policy, did not join in this brief, the fact that, as noted, the Catholic League for Religious and Civil Rights did file a separate amicus brief urging the same points certainly conveyed to the legislators the reality that the Church too favored enactment of the measure.

In sum, while amici briefs in church-state conflicts may have only occasional demonstrable effect on the Supreme Court's decisions, they often have substantial influence in legislative achievement of the outcome urged in the briefs.

158. 158 U.S. 601 (1895).

159. 366 U.S. $599(1961)$.

160. 366 U.S. 617 (1961).

161. 101 S. Ct. 270 (1980). 